\title{
IMPROVING THE EFFICIENCY OF INDUSTRIAL ENTERPRISES THROUGH THE MECHANISMS OF MOTIVATION
}

\author{
V.V. Zakharov, metkol@yandex.ru \\ South Ural State University, Chelyabinsk, Russian Federation
}

\begin{abstract}
Any company manages the financial, material and human resources, but human resources management is able to ensure that all plans and achieve its objectives. A modern company should develop and update personnel policies, adhering to a system approach. It is important to understand that the need to invest in human resources. Only then the company will take its rightful position in the market, will continue to develop. This thought leads to the realization that human resource management cannot be limited only to administrative activities related with personnel.

The article discusses the possibility of increasing the productivity of the personnel by improving the intrinsic motivation and stimulation of employees.

Keywords: personnel motivation, personnel management.
\end{abstract}

Introduction Management of industrial enterprises in modern conditions requires from their managers, given the increasing number of various factors, understanding of different processes within the company. The modern manager must focus on establishing effective economic enterprises linked to global economic processes and government economic policy.

To evaluate the economic policy of the company should be considered:

1) efficiency of production (labor productivity, capital productivity, product yield, labor intensity, capital intensity, consumption ratios);

2) efficiency of economic activities (margin costs, the share of current expenditure in the revenue from sales, the share of operating income in the income from sales, ongoing cost recovery factor income from sales of products);

3) efficiency of financial-economic activity (coefficient of business activity, return on sales, return on equity) [1].

The General principle of calculation of indicators of efficiency is that they correlated the obtained result and the resources spent on obtaining this result. Here are the performance indicators of two types:

- direct (resource productivity): the ratio of results to resources;

- back (carrying capacity): the ratio of resources to results.

For modern industrial enterprises the possibility of improving the efficiency of its functioning are associated largely with the following:

- right choice of mission, the definition of the company's goals and objectives;

- the formation method and models of the company;

- devising reserves improve productivity, increase profitability, and profitability of the enterprise, optimizing the costs for raw materials and materials, energy consumption, etc.;

- using modern techniques of production logistics and the latest energy-efficient industrial technologies;

- using relevant tools and systems receiving, storing and processing information and the corporate information system of the industrial enterprise;

- policy on human resource management (qualification, experience and knowledge of staff are the main advantage that distinguishes successful companies from mediocre ones) $[2,3]$.

A modern company should develop and update personnel policies, adhering to a system approach. It is important to understand that the need to invest in human resources. Only then the company will take its rightful position in the market, will continue to grow.

The most important indicators of the effectiveness of personnel policy is the achievement of the strategic objectives of the company [4]. 
At the Russian enterprises it is necessary to create the same organizational culture as in the world's leading companies. This means to create conditions under which every worker will be disciplined organization, the executive and high performance. It needs to develop rules for effective teamwork and a special mechanism of motivation, stimulating the staff to up their strict implementation.

The motivation system in the company should cause employees to do their job. To make the system of personnel motivation was effective, it is necessary to observe two conditions: to have reliable information about the current needs of employees and create a working environment in which it would be possible to achieve their personal goals and the goals of the company.

The effectiveness of performing professional activities have a significant impact two main factors: professional motivation and professional activities. Professional motivation makes the employee readiness to work, maintain interest in her progress, reveals what man is and what he strives for. It also includes professional calling, which is associated with the professional intentions of the individual. In a basis of motives of professional activity lie need for professional labor and value orientation [5].

The effectiveness of professional activity, according to many authors, is closely related to success in the profession. In turn, improving the efficiency of enterprises currently possible largely due to the increase in the level of productivity of staff, which requires more managerial attention, and the integrity of the system of personnel motivation plays an important role. There should be clear instruments and incentives for the implementation of the system of motivation.

It is known that the interest of employees in successful and productive activities of the enterprise and its economic feasibility is higher when more motivating for employees. In the end, this leads to increase of efficiency of work of all collective of the enterprise and has a positive impact on the overall performance of the entire organization [6].

Motivation is widely seen throughout the history of the world economy. However, it is currently impossible to say that there is a universal tool of motivation. In addition, the classical approach does not give the expected results in the current environment. Thus, the need to identify new approaches to motivation is one of the main components of the further growth of personnel management in any organization, including an industrial enterprise.

Balanced development of the enterprise and its steady growth is directly dependent on personnel management and require a full commitment from employees, which can be achieved through the detection of intrinsic motivation. But the concept of intrinsic motivation does not imply a quantitative assessment of motivational characteristics, and therefore extremely difficult to understand the relationship of increasing internal motivation and efficient management of the entire organization.

New tools of motivation of the entity is required to assess the level of intrinsic motivation of staff, forecasting of labor productivity growth and risk assessment implementation of the policy of motivation, which is based on internal incentives.

It should be noted that intrinsic motivation is the desire to perform certain tasks without a particular reason, whereas extrinsic motivation implies a deliberate, including intangible incentives from the management. A special role for monetary reward. At first glance, the interdependence between the level of motivation and wages are certainly high. Money is traditionally considered the main factor that makes employees work better. Thus, a permanent increase in salary or extra bonuses can be considered an effective, universal motivation. These incentives may not necessarily be expressed in the form of direct wage increases. They can be in the form of bonuses, special allowances, and also provide the indirect benefits, such as free Parking, membership of a trade Union, assistance in obtaining necessary education, corporate loans, etc. Financial motivation is the easiest way to influence the organizational behavior of employees $[7,8]$.

In addition, the rapid and continuous changes in market needs and regulatory acts, control the production process of an industrial enterprise, entail an adjustment of production, which in turn require continuous training. continuous learning motivation in many foreign companies is the relationship between the results of production activities of each employee and giving him the opportunity to study: the value of an employee of the company determines the amount of funds allocated to improve his skills. Thus, a more efficient and cost effective for the organization is to increase the impact of existing employees based on their continuing education than to attract new employees.

The set of monetary motivation and increase efficiency of the enterprise will help to attract and retain the most talented employees. In most cases, the best students are attracted to organizations that use 


\section{Краткие сообщения}

a pay system related to its performance. Thus, to be effective, enterprises should benefit from the financial rewards, contributing to long-term staff loyalty.

However, we should not forget that the best employees can't be truly loyal to the company, where the high salary is the only advantage. Indeed, the monetary aspect is a key factor in the effectiveness of the staff, but not the only one. When applying for a job salary estimated as a key factor for the final decision, but after employment, its role may change.

Undoubtedly, today's workers require an adequate assessment of their efforts, which is expressed in wages. However, in addition to the fair payment of their work, the staff needs some degree of autonomy in setting goals, time and manner of their achievement, support the organization of self-development and professional growth and, of course, getting pleasure from the work itself. These principles are the key aspects of intrinsic motivation.

Thus, the mechanism of intrinsic motivation can be applied using the following components: choice and variability of working conditions, commitment to continuous professional development, impact of the work on achieving the personal goals of the employee, possibilities of self-realization and self-assertion, and communication needs.

This integrated approach will allow us to determine the influence of motivation on the final result of the activity, both the employee and the entire management policy and its effectiveness.

\section{References}

1. Maksimov, A.A. [Human Resource Management in JSC "Kuznetsk Ferroalloys"]. Fundamental Methods, Models and Tools for Analysis and Data Processing in Information Systems of the Executive Bodies: Scientific Proceedings. Chelyabinsk, South Ural St. Univ. Publ., 2010, pp. 154-190. (in Russ.)

2. Korennaya K.A. [Approach, Methods and Human Resources Management Model as the Most Important Components of the Modern Concept of an Industrial Enterprise]. Proceedings of the Universities. Ural region, 2012, no. 3. pp. 47-61. (in Russ.)

3. Korennaya K.A., Loginovsky O.V., Maksimov A.A. Upravlenie promyshlennymi predpriyatiyami $v$ usloviyakh globalnoy nestabilnosti: monografiya [Management of Industrial Enterprises under Global Instability: Monograph]. Chelyabinsk, South Ural St. Univ. Publ., 2013. 403 p.

4. Loginovsky O.V., Maksimov A A. Upravlenie gruppoy predpriyatiy: uchebnoe posobie [Management of the Group of Enterprises: Textbook]. Chelyabinsk, South Ural St. Univ. Publ., 2008. 217 p.

5. Markova A. K. Psikhologiya professionalizma [Psychology of Professionalism]. Moscow, International Humanitarian Fund "Znaniye" Publ., 1996. 55 p.

6. Pink D.H. Drive: The Surprising Truth about What Motivates Us. Great Britain: Canongate Books Ltd., 2010. 242 p.

7. Fidelman G.N., Dedikov S.V., Adler Y.P. Alternativnyy menedzhment: put $k$ globalnoy konkurentosposobnosti [Alternative Management: the Path to Global Competitiveness]. Moscow, Alpina Publ., 2005. 186 p.

8. Alekseenko V.B., Ivanova T.B. Kak dostich effektivnosti v upravlenii biznesom [How to Achieve Efficiency in Business Management]. Moscow, Publ. of People's Friendship University, 2010. 214 p.

Received 25 May 2016 


\title{
ПОВЫШЕНИЕ ЭФФЕКТИВНОСТИ ДЕЯТЕЛЬНОСТИ ПРОМЫШЛЕННОГО ПРЕДПРИЯТИЯ ЗА СЧЕТ МЕХАНИЗМОВ МОТИВАЦИИ ПЕРСОНАЛА
}

\author{
B.B. Захаров \\ Южно-Уральский государственный университет, г. Челябинск
}

\begin{abstract}
Любое предприятие управляет финансовыми, материальными и человеческими ресурсами, но только кадровый менеджмент способен обеспечить выполнение всех намеченных планов и достижение поставленных целей. Современная компания должна разрабатывать и обновлять кадровую политику, придерживаясь системного подхода. Важно понимать, что необходимо вкладывать средства в человеческие ресурсы, только тогда компания займет достойное положение на рынке, будет и дальше развиваться. Эта мысль ведет к осознанию того, что управление человеческими ресурсами не может быть ограничено только лишь административной деятельностью связанной с персоналом.

В статье рассматривается возможность увеличения производительности труда персонала благодаря повышению внутренней мотивации и стимулированию сотрудников.

Ключевые слова: мотивация персонала, управление персоналом.
\end{abstract}

\section{Литература}

1. Максимов, А.А. Управление человеческими ресурсами в ОАО «Кузнеикие ферросплавы» / А.А. Максимов, К.А. Коренная // Методы, модели и средства анализа и обработки данных в информационных системах органов исполнительной власти: науч. тр. / под ред. засл. деят. науки РФ, д.т.н., проф. О.В. Логиновского. - Челябинск; Изд-во ЮУрГУ: ЦНТИ, 2010. - С. 154-190.

2. Коренная, К.А. Подход, методы и модели управления трудовыми ресурсами как важнейшие составляющие современной конщепщии управления промыщленным предприятием / К.А. Коренная // Известия вузов. Уральский регион. -2012. - № 3. - C. 47-61.

3. Коренная, К.А. Управление промышленными предприятиями в условиях глобальной нестабильности: моногр. / К.А. Коренная, О.В. Логиновский, А.А. Максимов; под ред. д-ра техн. наук проф. А.Л. Шестакова. - Челябинск: Издат. иентр ЮУрГУ, 2013. - 403 с.

4. Логиновский, О.В. Управление группой предприятий: учеб. пособие / О.В. Логиновский, А.А. Максимов. - Челябинск: Изд-во ЮУрГУ, 2008. - 217 с.

5. Маркова, А.К. Психология профессионализма / А.К. Маркова. - М., 1996. - 55 с.

6. Pink, D.H. Drive: The Surprising Truth about What Motivates Us / Daniel H. Pink. - Great Britain: Canongate Books Ltd., 2010. - 242 c.

7. Фидельман, Г.Н. Альтернативный менеджмент: путь к глобальной конкурентоспособности / Г.Н. Фидельман, С.В. Дедиков, Ю.П. Адлер. - М.: Альпина, 2005. - 186 с.

8. Алексеенко В.Б. Как достичь эффективности в управлении бизнесом / В.Б. Алексеенко, Т.Б. Иванова - М.: Изд-во РУДН, 2010. - 214 с.

Захаров Вадим Владимирович, аспирант кафедры информационно-аналитического обеспечения управления в социальных и экономических системах, Южно-Уральский государственный университет, г. Челябинск; metkol@yandex.ru.

Поступила в редакцию 25 мая 2016 г.

\section{ОБРАЗЕЦ ЦИТИРОВАНИЯ}

Zakharov, V.V. Improving the Efficiency of Industrial Enterprises through the Mechanisms of Motivation / V.V. Zakharov // Вестник ЮУрГУ. Серия «Компьютерные технологии, управление, радиоэлектроника». 2016. - T. 16, № 3. - C. 168-171. DOI: 10.14529/ctcr160319

\section{FOR CITATION}

Zakharov V.V. Improving the Efficiency of Industrial Enterprises through the Mechanisms of Motivation. Bulletin of the South Ural State University. Ser. Computer Technologies, Automatic Control, Radio Electronics, 2016, vol. 16, no. 3, pp. 168-171. DOI: 10.14529/ctcr160319 